Acta Horticulturae et Regiotecturae 1

Nitra, Slovaca Universitas Agriculturae Nitriae, 2018, pp. 5-9

\title{
RIVER BASIN HYDROLOGICAL BALANCE EVALUATION IN TERM OF THE LAND USE CHANGE IMPACT
}

\author{
Beáta NOVOTNÁ1*, Ján ČIMO , Branislav CHVÍLA², Gabriela POZNÍKOVÁ ${ }^{3}$ \\ ${ }^{1}$ Slovak University of Agriculture in Nitra, Slovak Republic \\ ${ }^{2}$ Slovak Hydrometeorological Institute in Bratislava, Slovak Republic \\ ${ }^{3}$ Czech Globe: Global Change Research Institute, Academy of Sciences, Brno, Czech Republic
}

\begin{abstract}
Assessment of the land use impact on the processes of water balance in the river basin should be an indispensable part of integrated river basins management. This paper compares climatic conditions occurring during the long-term period (1951-1980), following the situation immediately after dry conditions (1993-1999) and extremely rainy dates (2009-2012) with emphasis to estimate the runoff components in the Žitava river basin: the Obyce sub-catchment, situated in its upper part $\left(74.5 \mathrm{~km}^{2}\right)$ in the Slovak Republic. Modelling of the land use change effect on the total hydrology balance of the river basin characteristics was performed using the hydrological model WaSiM-ETH. The model was applied to evaluate the vegetation type influence and the water balance change in the presently mostly forested river basin (1), altering its replacement by the permanent grasses (2) and bushes (3), with emphasis to different total water balance characteristics change. The present state land use data were taken from the Corine Land Cover of the Slovak Republic. Model results show that actual evapotranspiration would decrease from $-1.3 \%$ in case of bushes in 2009 up to $-32.5 \%$ in case of grass in 2011. However, $13.3 \%$ rise was considered for bushes in 2010. Total annual discharge shows its increment in all observed changes from 5.9\% for bushes in 2010 up to 65.3\% for grass in 2012. Only in case of bushes in 2011 there was observed slight decrease of about $-3.1 \%$. Regarding the very expected land use change, especially in connection with the ongoing global climate change, the estimation of the hydrology balance components is of utmost significance.
\end{abstract}

Keywords: climate characteristics, total water balance, river basin, hydrological model, land use change

Sustainable water management requires the quantification of spatial and temporal changes of water balance variables (Wagner, Kunstmann and Bárdossy, 2006). In Slovakia, hydrological models have recently been used to assess the impacts of land use and climate change on drainage and snow melt processes and simulation of sediments transport. Possible changes of the runoff characteristics, caused be modifications of land use features, represent one of the main sources of uncertainty in the area of water resources management and in flood protection (Jurík et al., 2008).

Identifying changes in runoff and quantifying the impacts of climate change and human activities are of great significance for water resources planning and management in a river basin (Zhang et al., 2017). The hydrological processes are very complex and highly non-linear. Models based on the linear system theory generally fail to represent the non-linear processes (Raveendra, Rai and Mathur, 2008). In this study, there were used alternations applying the hydrological model in order to identify the trends of the hydrological components responses to climate changes in connection with land use, which is a well-established tool for investigating the spatial and temporal variability of hydrological processes in a complex river basin.

The river basin response to vegetative changes is predictable (Bulantová, 2009). However, there are conflicts between the science and the public perception of land and forest use and hence the impact on the overall hydrological cycle of water in nature (Jewitt, 2005, in Bulantová (2009). As an example, there are two conflicting studies. The first one highlights that the forests, including soil and roots, behave like a "sponge" that draws water during precipitation and release it during drought. According to this study, forests should contribute to improving the water supplies by replenishing groundwater resources, maintaining the basic runoff and mitigating floods. In opposite, the second study states that roots do not release water during dry periods, but absorb it from the soil (Hamilton and King, 1983; Jewitt, 2005 in Bulantová, 2009).

The individual effect of forest vegetation in a particular river basin can be a very specific one, because the runoff is determined by a complex of factors, from those some may react adversely and thus complicate the behaviour of the entire rainfall-drainage system. For integrated river basin management, it is therefore advisable to examine each river basin or region separately and possibly verify several model approaches (Bulantová, 2009). The issue of the water balance in changed climate condition was also developed by Tátošová (2006), Bárek, Halaj and Takáč (2008) and Halaj et al. (2010). 


\section{Material and methods}

\section{Research area}

The Žitava river basin $\left(903 \mathrm{~km}^{2}\right)$ was chosen as a model area with $99.3 \mathrm{~km}$ of the total stream length. The Žitava is a partial sub-basin of the Nitra river basin. There is about $60.5 \%$ of the agricultural land in the sub-basin; forests represent about $32.5 \%$, built-up area covers $6.8 \%$, and water areas and other areas $0.2 \%$ and $0.1 \%$, respectively. During the years 2009 and 2012, flood events occurred; therefore the causes of such phenomena need to be analysed and appropriate measures to prevent them taken. From the whole Žitava river basin, the Obyce water gauge profile was chosen for evaluation of the river basin hydrological balance $\left(74.5 \mathrm{~km}^{2}\right)$, because it is mostly covered by a deciduous forest. For land use, there was applied the Corine Land Cover of the Slovak Republic, where land cover is a map of the surface of Europa from the LANDSAT satellites (see Figure 1a). Green areas represent forested areas and pink circle shows the Obyce profile water gauge station. Review of the profile water gauge stations in the Žitava river basin is showed in Figure $1 \mathrm{~b}$ ). The land use is very diverse in the catchment area from forest (the most common deciduous forests are: oak, hornbeam and beech trees, as well as coniferous forests: spruce or pine trees), through grazed meadows on the slopes of mountains to agriculture in the lower parts of the basin (Zorád, 2010).

Distribution of monthly average air temperature values and monthly average precipitation totals during the periods of years 1951-1980, 1993-1999 and 2009-2012 is displayed in Figures 2a) and 2b). Based on 30 years of data, period of the years 1951-1980 characterises "reference term."

The period of the years 1993-1999 represents the dry term. The seven years period (1988-1994) was the warmest and driest in Slovakia since 1871 (Smith et al., 1996). The period of the years 1989-1993 was the driest season in the middle and lower Danube region and the warmest consecutive three-year and five-year period was between 1998 and 2002, with the decades clearly dominating the 1990s (Blinka, 2009).

The period of the years 2009-2012 characterises the wet term. Zeleňáková et al. (2017) analysed the temporal and spatial precipitation distribution trends over Slovakia, utilizing 487 gauging stations; in 1981-2013 it showed that annually, there was a significant, although only slightly increasing precipitation trend. The absolutely highest precipitation total on an annual scale was in 2010. However, from the monthly point of view, there is evidence of a very different rain distribution over the studied area.

Even though the second and third periods are inadequate to distinguish between changes due to long-term trends, they indicate inter-annual and inter-period variability.

\section{Hydrological model}

The hydrological Water Flow and Balance Simulation Model (WaSiM-ETH) was used (Schulla, 1997) to inspect the hydrological balance alteration under the possible modified land use characteristics due to the global atmosphere change in near future. Richard's equation is composed for unsaturated zone modelling. Main parameters of this model

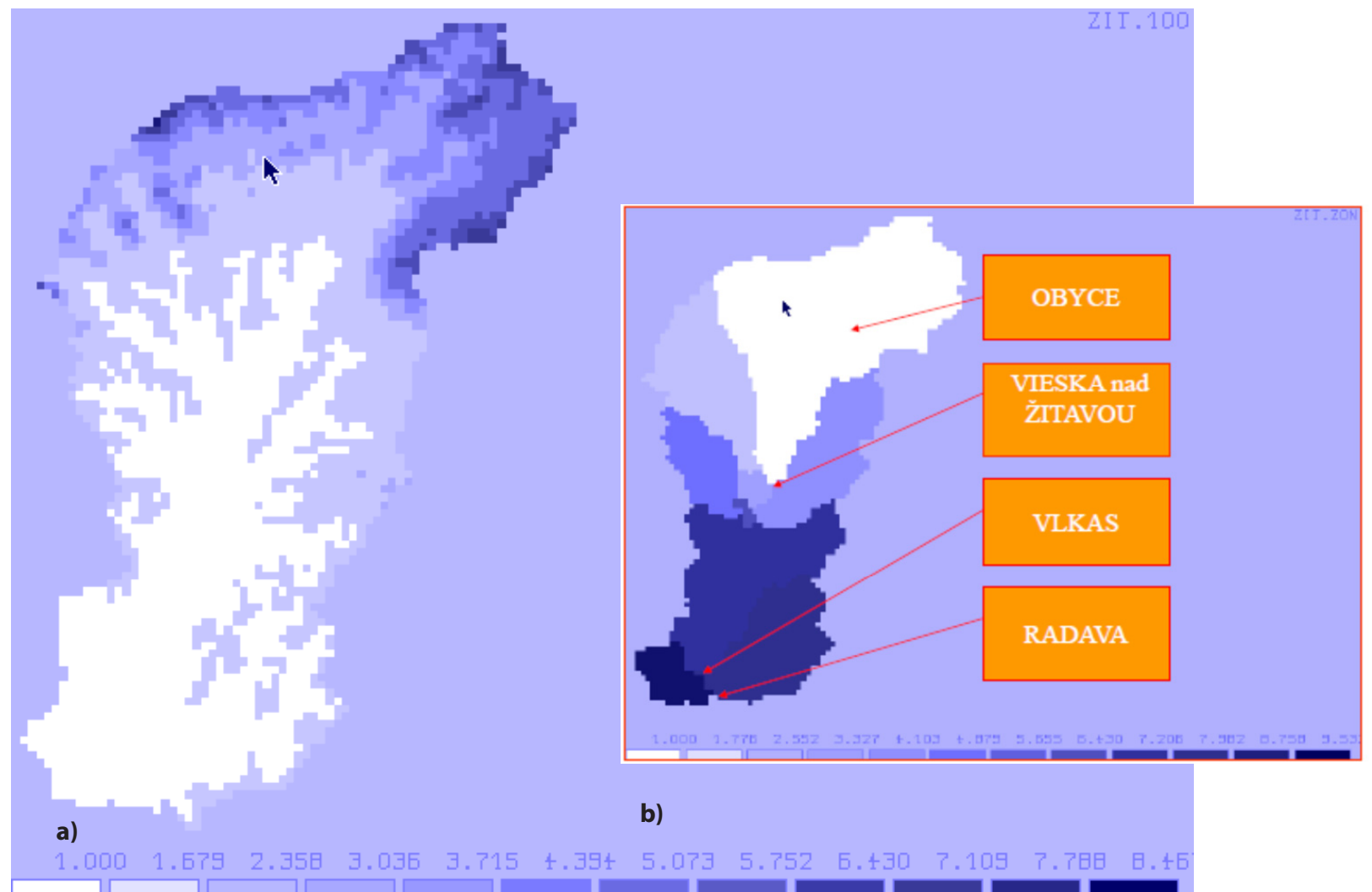

Fig. 1 a) Digital elevation model of Žitava river basin with a spatial resolution on regular grids of a cell size of $100 \times 100 \mathrm{~m}$.; b) Map situation of Žitava individual sub-basins, arrows show the specific water gauge stations: Obyce, Vieska nad Žitavou, Vlkas and Radava in Žitava river basin 


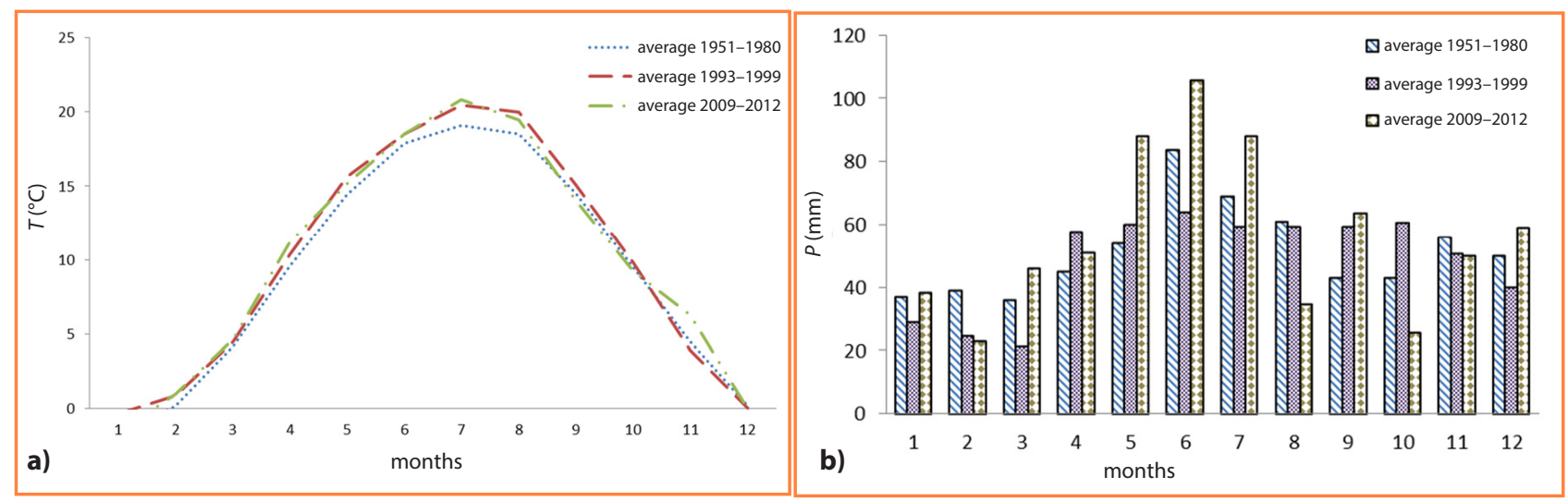

Fig. 2 a) Monthly course of the mean air temperature $T\left({ }^{\circ} \mathrm{C}\right)$ values during the observed periods: 1951-1980, 1993-1999 and 2009-2012; b) Monthly values of the mean precipitation totals P (mm) during the observed periods: 1951-1980, 19931999 and 2009-2012

are: full surface runoff distribution, time step 1 day, spatial resolution on regular grids with a cell size of $100 \times 100 \mathrm{~m}$. Input climate data in daily time step were: air temperature $\left({ }^{\circ} \mathrm{C}\right)$ (10 stations), precipitation totals $(\mathrm{mm})$ (16 stations), global radiation (Wh. $\mathrm{m}^{-2}$ ) (2 stations), relative sunshine duration (hours) (1 station), vapour pressure (mbar) (4 stations), wind speed $\left(\mathrm{m} . \mathrm{s}^{-1}\right)$ (8 stations). Model routines are: precipitation correction, input meteorological data interpolation according to different methods, snow accumulation and its melting using inverted distance weighting methods, plant interceptions modelling using a leaf area index depending on the interception reserve, infiltration model used by
Green-Ampt. Within the model, outflow is defined as the total amount of water that flows out of the river basin per time unit. According to Cudlin et al. (1999) it is divided into surface, subsurface (hypodermic) and underground direct and base discharge. Direct runoff is also specified within a model, what is a summary designation for the surface and leakage subsurface effluent that still has not reached the groundwater level yet during the precipitation duration or immediately after the precipitation event (Pavková, 2010). Hydrological model calibration was performed during the period: 1993-1999 (coefficient of determination: $r^{2}=0.71$ ) and validation: $2009-2012\left(r^{2}=0.79\right)$. During the calibration,

Table 1 Evaluation of the hydrological balance in term of the land use change impact related to the Žitava sub-catchment, the Obyce water gauge profile, using the results of the WaSiM-ETH model

\begin{tabular}{|c|c|c|c|c|c|c|c|}
\hline 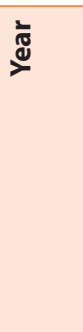 & 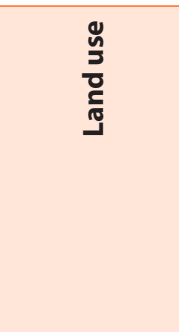 & 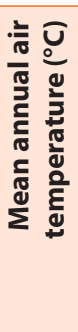 & 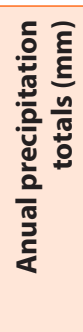 & 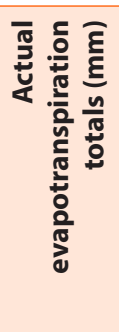 & 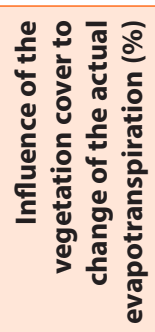 & 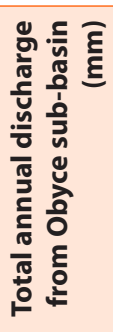 & 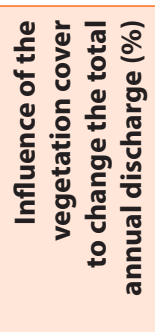 \\
\hline \multirow{3}{*}{2009} & present state & 10.7 & 885 & 429 & & 142 & \\
\hline & grass & & & 346 & -19.4 & 225 & 58.4 \\
\hline & bushes & & & 423 & -1.3 & 177 & 24.7 \\
\hline \multirow{3}{*}{2010} & present state & 9.5 & 1,352 & 524 & & 454 & \\
\hline & grass & & & 355 & -32.3 & 684 & 50.8 \\
\hline & bushes & & & 594 & 13.3 & 481 & 5.9 \\
\hline \multirow{3}{*}{2011} & present state & 10.5 & 763 & 590 & & 242 & \\
\hline & grass & & & 398 & -32.5 & 386 & 59.4 \\
\hline & bushes & & & 548 & -7.0 & 235 & -3.1 \\
\hline \multirow{3}{*}{2012} & present state & 11.1 & 895 & 522 & & 232 & \\
\hline & grass & & & 411 & -21.3 & 383 & 65.3 \\
\hline & bushes & & & 496 & -5.1 & 254 & 9.7 \\
\hline
\end{tabular}

Individual land use changes are under the same climate conditions: 1 . for the present time land use, e.g. mostly forested river basin, 2. replaced by permanent grasses, 3 . replaced by bushes 


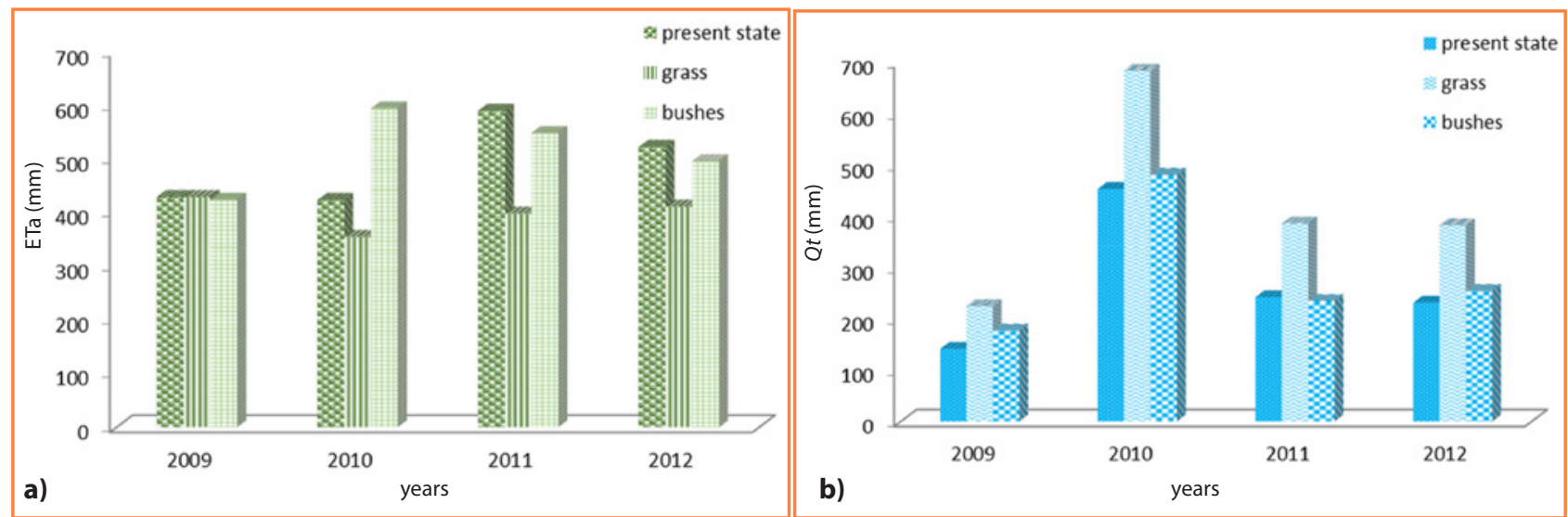

Fig. 3 a) Annual totals of actual evapotranspiration ETa in $\mathrm{mm}$ expressed for: present state of the land use, grass, bushes in the period of the years 2009-2012; b) Total annual discharge sums Qt in mm expressed for: present state of the land use, grass, bushes in the period of the years 2009-2012 in the Obyce catchment

total discharges computed by the model were compared with the real total discharges data measured in the Obyce profile.

\section{Results and discussion}

Annual mean air temperature during the evaluated period 2009-2012 was $10.4{ }^{\circ} \mathrm{C}$, average value of the annual precipitation totals was $974 \mathrm{~mm}$ and average annual actual evapotranspiration totals was $473 \mathrm{~mm}$. These whole climate characteristics data were used as input data to calibrate and verify model results according to Novotná (2004). Evaluation of water balance in the Obyce profile, according to the individual land use change, but under the same climate conditions was performed for the present time land use, e.g. mostly forested river basin (1), replaced by permanent grasses (2) and replaced by bushes (3) using model WaSiMETH. The model results are displayed in Table 1.

According to the model results, under the consideration of the same climate characteristics, changing only land use exploitation from the present state: deciduous forest 1) to grass and bushes 2 ) in all cases there was reported the actual evapotranspiration decrease from the smallest $-1.3 \%$ for bushes in 2009 up to the $-32.5 \%$ for grass in 2011 . Only one increase is considered equal to $13.3 \%$ for bushes in 2010 .

Similarly, the influence of the vegetation cover to the change of the total annual discharge was established in all cases from $5.9 \%$ for bushes in 2010 up to $65.3 \%$ for grass in 2012. The only reduction $-3.1 \%$ was considered for bushes in 2011.

The comparison of the annual totals of actual evapotranspiration ( $\mathrm{mm}$ ) 3a) and total discharges related to the water gauge profile Obyce $(\mathrm{mm})$, during the individual years is displayed in Figure $3 a$ ) and $3 b$ ).

\section{Conclusions}

Influenced by land use changes, significant hydrological cycle modifications are expected to occur in the observed sub-basin according to the results. These changes are identified and attributed to climate change, especially the decreased precipitation and the increased air temperature, in accordance with the study of Zhang et al. (2017). This study provides insights into changes in hydrological balance distribution and water resources availability that may occur as the result of global change in small-scale mostly forested sub-basin.

The results underline the importance of the forest communities in the water cycle and in the nature. Forests are related to the water balance through the processes of evaporation, evapotranspiration, infiltration, transpiration, and interception - the important functions of forest ecosystems.

The land-use/land-cover change is a widespread, accelerating, and significant process. Modelling these changes is critical for formulating effective environmental policies and management strategies (Agarwal et al., 2002). While assessing the effects of climate change at global or regional scales, local factors responsible for climate change are generalized, which results in the averaging of effects. However, climate change assessment is required at a microscale to determine the severity of the climate change. This shows the contribution of land use/land cover change and several other local anthropogenic activities on the climate change (Pingale et al., 2015).

The results of our study agree with Holko (2010) who states that possible technical measures to increase landscape retention have to be compared with the data about probable rainfall amount and intensity in the given area. In conditions of less permeable areas, where the main runoff formation mechanism is a surface runoff caused by exceeding of the soil infiltration capacity, it has to be taken into consideration that the measures performed to increase the soil infiltration capacity do not cause disruption of the soil surface. Hydrological response to the river basin, possibly leading to floods, depends on many factors. However, hydrological models provide the detailed information about the runoff formation and about the most frequent causes of floods in our territory as well as the most threatened areas. Present technologies make it possible, with some likelihood and precision, to alert the flooding risk and compute the flood wave characteristics and possible extent of the flooded area.

The results of this study can be useful for the identification of optimal climate change adaptation and 
mitigation strategies based on the severity of climate change at different spatial scales as it was proposed by Pingale et al. (2015). Possible parameters change estimation of the extreme runoff phases due to global climate change, in the design of adaptation and mitigation measures for water management as well as to evaluation the land use characteristics in terms of the risk of floods were also intended by Húska and Tátošová (2005).

\section{Acknowledgement}

The results obtained in the research project KEGA no.004SPU-4/2016 was used/presented in this paper.

\section{References}

AGARWAL, CH. - GREEN, G. - GROVE, J.M. - EVANS, T.P. - SCHWEIK CH.M. 2002. A review and assessment of land-use change models: dynamics of space, time, and human choice. Gen. Tech. Rep. NE297. Newton Square, PA: U.S. Department of Agriculture, Forest Service, Northeastern Research Station, 2002.61 p.

BÁREK, V. - HALAJ, P. - TAKÁČ, J. 2008. Assessment of the moisture demand for the special crops and vegetables in changed climate conditions of Slovakia. In Acta horticulturae et regiotecturae, vol. 11, 2008, no. 1, p. 9-13. ISSN 1335-2563.

BLINKA, P. 2009. Climatic assessment of drought in Czech and Moravia during the years 1875-2002. Disertation Thesis : Praha UK, 2009, $139 \mathrm{p}$.

BULANTOVÁ, M. 2009. Assessing the impact of forests on drainage processes in river basins. In $21^{\text {th }}$ Conference of Young Hydrologists, Bratislava : Sloval Hydrometeorological Institute, 2009, 14 p. ISBN 978-80-88907-70-1. [on-line]. Available on: <http://www.zzvh.sk/ data/files/70.pdf> [cit. 2018-03-01].

CUDLíN, P. et al. 1999. Příčiny snížení vodohospodářské funkce lesa v krajině. Závěrečná zpráva úkolu VaV 610/2/98, DÚ 01/07. České Budějovice : Ústav ekologie krajiny AV ČR, 1999, 84 p.

HALAJ, P. - BOŽOŇ, V. - HORNÍKOVÁ, H. - BÁREK, V. - ČIMO, J. TÁTOŠOVÁ, L. - ĎURIŠ, J. 2010. Hydraulic stream habitat study based on acoustic doppler velocity measurements. In Journal of International Scientific Publications: Ecology \& Safety, vol. 4, 2010, no. 1, pp. 192-200. ISSN 1313-2563.

HAMILTON, L.S. - KING, P.N. 1983. Tropical Forested Watersheds: Hydrological and Soil Response to Major Uses for Conservation, Westview Press : Boulder, 1983.

HOLKO, L. 2010. Voda v krajine a povodne. In Urbanita, vol. 22, 2010, no. 4, pp. 20-24.

HÚSKA, D. - TÁTOŠOVÁ, L. Sustainable land use in hilly areas. In Protection of soil and water resources in forestry areas. Warsaw Forest Research Institute, 2005, pp. 143-146. ISBN 83-87647-38-1.
JEWITT, G. 2005. Water and Forests. In Encyclopedia of Hydrological Sciences (Ed. Anderson, M. G. - McDonnell, J.J. ), chapter 186, John Wiley \& Sons, Ltd., 2005, pp. 2895-2909.

JURÍK, L. - HÚSKA, D. - TÁTOŠOVÁ, L. - BAZSÓ, R. 2008. Water for landscape or landscape for water. In Zeszyty problemowe postepów nauk rolniczych, 2008, no. 532, pp. 121-131. ISSN 0084-5477.

NOVOTNÁ, B. 2004. Influence of the climate change on the need of water demand for irrigation in Žitava river basin. Disertation Thesis : Nitra : SAU, 2004.

PAVKOVÁ, K. 2010. Modelling of the surface runoff in ArcGIS Server. Palacky University in Olomouc, Olomouc, [on-line]. Available on: $\quad<$ http://www.geoinformatics.upol.cz/dprace/magisterske/ pavkova10/model.html> [cit. 2018- 2-28].

PINGALE, S. - ADAMOWSKI, J. - JAT, M. - KHARE, D. 2015. Implications of spatial scale on climate change assess- ments. In Journal of Water and Land Development, 2015, no. 26, p. 37-56.

RAVEENDRA, K. - RAI, B. - MATHUR, S. 2008. Event-based sediment yield modeling using artificial neural network. In Water Resour. Manag., 2008, no. 22, pp. 423-441.

SCHULLA, J. 1997. Hydrologische Modellierungvon Flussgebieten zur Abschätzung der Folgen von Klima änderungen. Diss ETH 12018, Zürich : Verlag Geographisches Institut ETH, 1997, 187 p.

SMITH, J.B. - HUQ, S. - LENHART, S. - MATA, L.J. - NEMESOVA, I. TOURE, S. 1996. Vulnerability and Adaptation to Climate Change: Interim Results from the U.S. Country Studies Program. Dordrecht, The Netherlands : Kluwer, 1996, 366 p.

TÁTOŠOVÁ, L. 2006. Possibilities of precipitation water interception in the landscape. In Inžynieria srodowiska, 2006, no. 434, pp. 185193. ISSN 1233-569X.

WAGNER, S. - KUNSTMANN, H. - BÁRDOSSY, A. 2006. Model based distributed water balance monitoring of the White Volta catchment in West Africa through coupled meteorological-hydrological simulations. Advances in Geosciences, European Geosciences Union, 2006, no. 9, pp. 39-44. <hal-00296954>.

ZELEŇÁKOVÁ, M. - VIDO, J. - PORTELA, M.M. - PURCZ, P. BLIŠTÁN, P. - HLAVATÁ, H. - HLUŠTÍK, P. 2017. Precipitation Trends over Slovakia in the Period 1981-2013. In Water, vol. 9, 2017, no. 12, p1-20, $20 \mathrm{p}$.

ZHANG, Y. - ZHONG, P.A. - CHEN, J. - BING, J. - XU, D. - WANG, M. 2017. Impacts of Climate Change and Human Activities on the Three Gorges Reservoir Inflow. In Water, vol. 9, 2017, no. 12, 57 p. doi:10.3390/w9120957

ZORÁD, L. 2010. Simulation of flood zones at Žitava river and stream Hostiansky. In Proceedings of the scientific work of PhD students and young scientists "Young Scientists 2010", Nitra : UKF, 2010. 